\title{
Toxicity Test of Muara Jambi Areca Nut (Areca Catechu L.) Extract on Rat Bone Marrow-derived Mesenchymal Stem Cells
}

\author{
Humaryanto $^{1 *}$, Esa Indah Ayudia ${ }^{2},{ }^{*}$ Muhaimin $^{3}$, Silmi Mariya ${ }^{4}$ \\ ${ }^{123}$ Faculty of Medicine and Health Sciences, Jambi University \\ ${ }^{4}$ Primate Research Center, Research Institutions and Community Service of IPB University, Bogor \\ *Corresponding author. Email : humaryanto_fkik@unja.ac.id
}

\begin{abstract}
Osteoarthritis $(\mathrm{OA})$ is a joint inflammation process that happens when chondrocytes failure in maintaining the balance between degradation and extracellular matrix synthesis. Thus, it results in changes in the diameter and orientation of collagen fibers that change cartilage biomechanics and make joint cartilage lose its unique compressibility properties. This case is increasing every year globally, including Indonesia, but no drug could effectively treat this disease until recently. The use of areca nut as traditional anti-inflammatory drugs has long been known, but the scientific evidence is lacking. This study aims to develop a simple in vitro OA model that is useful for predicting the ability of drugs to reduce cartilage hypertrophy by using the seeds of areca nut (Areca catechu L). In this study, the extraction and fractionation of areca nut (Areca catechu L) were carried out to obtain the active substances in the form of ethanol, alkaloid, and flavonoid compounds. Acute toxicity assessment using the Methyl thiazole tetrazolium (MTT) method resulted in LD50 $487.94 \mathrm{ppm}$. This shows that the Areca nut (Areca catechu L.) isolate is not toxic; therefore, it can be given as an alternative medicine for humans.
\end{abstract}

Keywords: osteoarthritis, areca nut, ethanol, alkaloids, flavonoids, MSC.

\section{INTRODUCTION}

Osteoarthritis (OA) is the most commonly found chronic joint disease and affects millions of patients worldwide. OA is one disorder often found in the field of orthopedic surgery because of the joint damages, especially in the knees, spine, and pelvis. The prevalence of OA increases significantly with age as shown by radiographic evidence observed in $>70 \%$ of the population aged $>65$ years. The etiopathogenesis of this disease, associated with OA development, is multifactorial, such as inflammatory processes, genetic predisposition, aging, obesity, and joint damage. Considering the widespread impact and consequences of this disease, no intervention has been proven to prevent the development of OA. According to WHO, in
2025, the elderly population in Indonesia will increase by $414 \%$ compared to those in 1990 . In Indonesia, the prevalence of knee OA that appears radiologically reaches $15.5 \%$ in men and $12.7 \%$ in women aged 40-60 years [1].

In the current era of globalization, the tendency to use herbal medicine has spread worldwide and is known as the "back to nature" lifestyle trend. Indonesia has abundant biodiversity that has not been optimally utilized. Therefore, traditional medicines that are encouraged to become Indonesian Modern Medicines (Obat Modern Asli Indonesia or OMAI) can be an alternative for the availability of drugs from Indonesian natural ingredients, thereby reducing the imports of medicinal raw materials. Currently, a few studies have focused on using plant medicines as an 
alternative and complementary form of osteoarthritis management.

Areca nut is one of the herbal ingredients consumed by some people in several regions of the world. People in Jambi, mostly men, also consume areca nuts, which are believed to increase their stamina. According to Nonaka et al. [2], areca nut contains proanthocyanidin, condensed tannin included in the flavonoid class. Proanthocyanidin has antibacterial, antiviral, anti-carcinogenic, antiinflammatory, anti-allergic, and vasodilating effects. Hydroalcoholic extract from Areca catechu L. (ANE) is known to have analgesic, antiinflammatory, and antioxidant potential in vitro [3]. Humaryanto et al. [4] studied the anti-inflammatory effect of yellow areca seed extract on the synovial layer and knee joints of white rats (Rattus Novergicus) model of osteoarthritis using intraarticular monoiodoacetate $1 \mathrm{mg}$ in the knee joint. Research using the True Experimental method with the Posttest Only Group Design found that histopathologically the Areca nut extract administration showed a mild inflammation up to normal synovial layer compared to control/meloxicam. The rats experienced a relatively sharp decrease in swelling diameter from the measurement of the knee joint diameter than the control/meloxicam.

The traditional use of areca nut (Areca catechu L.) as anti-inflammatory drugs has long been known, but the scientific evidence for this claim is lacking. This is the foundation for conducting an indepth study of areca seeds. This study aims to develop a simple in vitro OA model that is useful for predicting the drugs' ability to reduce cartilage hypertrophy by using areca nut (Areca catechu L) as an alternative material to inhibit the inflammatory process in the cases of osteoarthritis.

\section{RESEARCH METHODS}

The design of this study was experimental on the isolates of active substances of simplicia using cell culture techniques. This research was carried out in the Pharmacy laboratory of the Faculty of Science and Technology, University of Jambi and the biomedical laboratory of the Faculty of Medicine and Health Sciences, University of Jambi for the isolate manufacture and simplicia purity tests and also at the Laboratory of Microbiology and Immunology of the Primate Research Center IPB University Bogor for the 3-(4,5-Dimethylthiazol- 2- yl)-2,5-diphenyltetrazolium bromide (MTT) test. The simplicia of areca nuts was brown, appeared like marble, and had a bitter taste. The simplicia was stored in airtight containers to maintain minimum moisture content and prevent mold growth.

\subsection{Tools}

The tools used included maceration equipment, rotary evaporator, plethysmometer, and tools used in the screening and characterization process.

\subsection{Materials}

Areca nut (Areca catechu L.) was determined at the Pharmacy Laboratory of the Faculty of Science and Engineering, University of Jambi Mendalo, 70\% ethanol, distilled water, carrageenan (Sigma), Na-diclofenac (Novell), PGA, ammonia, chloroform, $\mathrm{HCl}$, gelatin solution, amyl alcohol, ether, vanilla solution, $\mathrm{H} 2 \mathrm{SO} 4 \mathrm{p}$, and $\mathrm{KOH}$. The reagents used were Mayer, Dragendorff, and Lieberman-Burchard reagents.

\subsection{Extraction}

The young Areca nuts were peeled, and the seeds were taken. The seeds were cleaned and cut into pieces. Then, they were put in an oven with a temperature of $30 \mathrm{oC}-50 \mathrm{oC}$ to remove the moisture. Special ethanol extract. Areca seeds were ground using a hammer mill. As much as 500gr of Areca nut powder was macerated with 1lt of $96 \%$ ethanol for $3 \times 24$ hours. The maceration was carried out twice. The extract was concentrated using a rotary evaporator.

Ethanol extract for partition and isolation. A total of $1 \mathrm{~kg}$ of powdered Areca nut was further macerated with 1.5 lt of $70 \%$ ethanol for $3 \times 24$ hours. The maceration was carried out twice. The extract was concentrated using a rotary evaporator [5].

\subsubsection{Partition}

\subsubsection{Crude flavonoid extract}

The concentrated ethanol extract obtained was dissolved in $500 \mathrm{ml}$ of distilled water. The solution was acidified using $2 \mathrm{M} \mathrm{HCl}$ to obtain a $\mathrm{pH}$ of 3 . The extract of this acidic water was partitioned with $100 \mathrm{ml}$ of hexane. The partition was repeated until 
the addition of hexane did not show any discoloration. The acid water layer obtained was then partitioned with $100 \mathrm{ml}$ ethyl acetate and repeated until the ethyl acetate appeared colorless. The ethyl acetate layer obtained was combined and determined as crude flavonoid extract (CFE). The CFE was concentrated using a rotary evaporator [6] [5].

\section{Crude alkaloid extract}

The acid water layer obtained from the partition to obtain CFE was alkalized with a $2 \mathrm{M}$ ammonia solution to a $\mathrm{pH}$ of 9 . This alkaline water extract was then partitioned with $100 \mathrm{ml}$ of ethyl acetate and repeated until the ethyl acetate no longer showed a color change. The ethyl acetate layers obtained were combined and designated as crude alkaloid extract (CAE). CAE was concentrated using a rotating vaporizer [7]. Phytochemical screening was carried out according to the standard procedure described by Harbone [8].

\subsection{Result Calculation}

$\%$ viability $=(1-($ OD control cell-OD treatment on cells $)) \times 100 \%$ OD control cell

$\%$ inhibition $=$ OD control cell - OD treatment on cells $\times 100 \%$ OD control cell

\section{DISCUSSION}

In this study, tests on secondary metabolites were conducted to determine the secondary metabolites in areca nut (Areca catechu L.) originating from the Muaro Jambi area. Secondary metabolites are metabolite compounds

\subsection{Bioactive compound screening using the MTT test}

Continuous cells that had been grown on the T25 flask were subcultured, then the cells were grown on 96 wells tissue culture plate with a total of 5000 cells/well and incubated for 24 hours in growth media at $37^{\circ} \mathrm{C}$ and $5 \% \quad \mathrm{CO}_{2}$. The bioactive compounds at each concentration were added as much as $100 \mu \mathrm{L} /$ well; untreated cells were included as control cells and then re-incubated for 48 hours. Compound 3-(4,5-Dimethylthiazol-2-yl)-2,5diphenyl tetrazolium bromide (MTT) was added and incubated for 4 hours at $37^{\circ} \mathrm{C}$ and $5 \% \mathrm{CO}_{2}$. The cell supernatant was discarded, the formed formazan crystals were dissolved with $70 \%$ ethanol. Optical density (OD) readings were performed using a microplate reader at a wavelength of $565 \mathrm{~nm}$.

that are not essential for the organism's growth and are found in different and unique forms from one species to another. Simplicia was then isolated to obtain active substances, namely the ethanol, alkaloid, and flavonoid components (Figure 1). The ethanol extract was carried out using a special ethanol extract technique through maceration and then concentrated with a rotary evaporator. Partition and isolation were carried out in order to obtain crude flavonoid extract and crude alkaloid extract. Complete results regarding the extraction results and examination of extract characteristics could be seen in Table 1. Then, the process was continued by phytochemical screening. The results of phytochemical screening could be seen in Table 2.

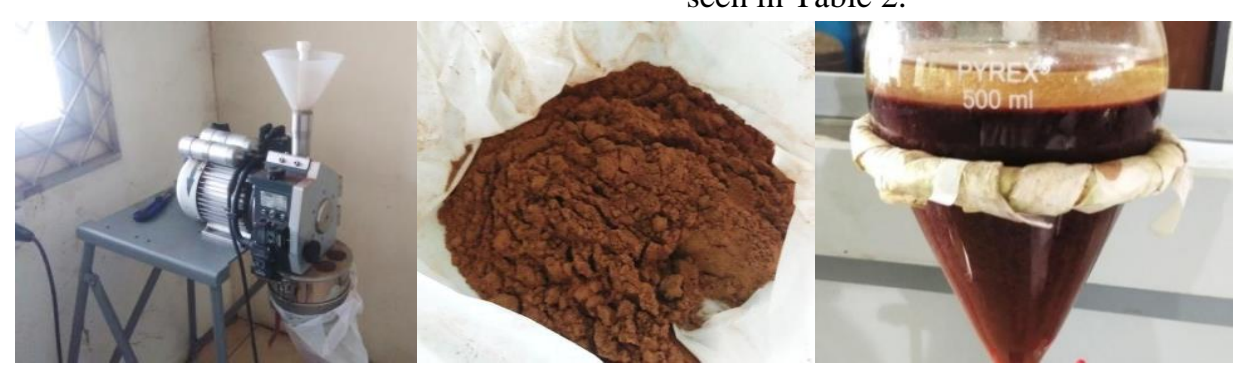




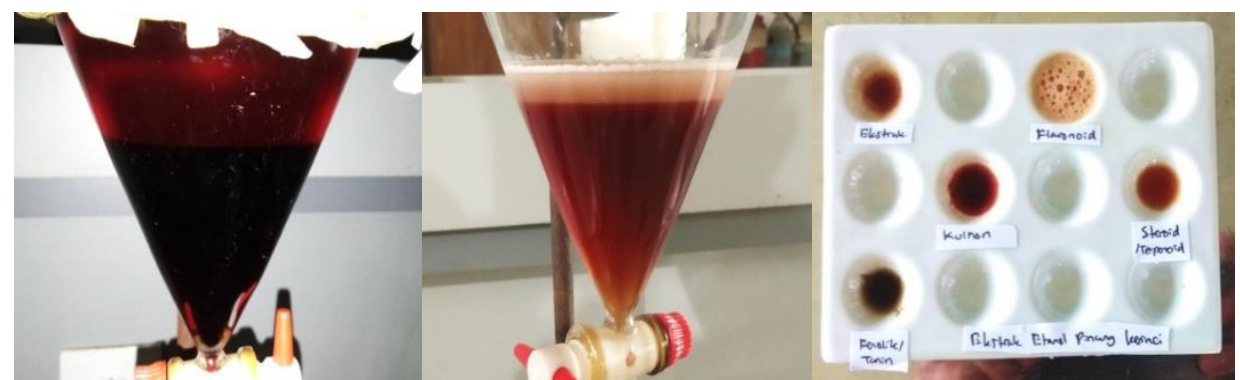

Figure 1. Areca nut extract isolate preparation

(Top images, left to right: Areca seed refinement process using a hammer mill. Refined Areca seed powder. Separation of acid water and ethyl acetate layer of areca nut EE. Bottom images, left to right: Separation of the acid water layer and ethyl acetate of areca nut EE. Separation of layers of alkaline water and ethyl acetate of EE areca nut. Phytochemical screening results for EE areca nut)

Table 1. Extraction and Partitioning

\begin{tabular}{lcc}
\hline Extract & Extract volume (I) & Mass of concentrated extract (g) \\
\hline EE Areca nut & 2.5 & 64.91 \\
CFE Areca nut & 2 & 10.83 \\
CAE Areca nut & 0.8 & 6.68 \\
\hline
\end{tabular}

Note: EE: ethanol extract; CFE: crude flavonoid extract; CAE: crude alkaloid extract.

Table 2. Phytochemical Screening

\begin{tabular}{lccc}
\hline & EE Areca nut & CFE Areca nut & CAE Areca nut \\
\hline Alkaloids & + & - & + \\
Flavonoids & + & + & - \\
Phenolic/Tannins & + & + & + \\
Quinone & + & + & + \\
Steroids & - & - & - \\
Terpenoids & - & - & - \\
Saponins & - & - & - \\
\hline
\end{tabular}

Note: EE: ethanol extract; CFE: crude flavonoid extract; CAE: crude alkaloid extract.

The results obtained from chemical compound tests showed that the ethanol extract of areca seeds contains alkaloids, tannins, saponins, and flavonoids. The chemical content test of the Areca nut ethanol extract was carried out to determine the dissolved compounds after the simplicia extraction process by using ethanol solvent. After discovering the compound content in the Areca nut ethanol extract, the working mechanism of the Areca nut ethanol extract can be estimated. Areca catechu contains 50\% - 60\% sugar, $15 \%$ fat (glyceride lauric, myristic, and oleic acid), $15 \%$ condensed tannins (phlobatnin and catechin), polyphenolics (NPF-86IA, NPF-86IB, NPF-86IIA, and NPF86IIB) and $0.2 \% \quad-0.3 \%$ alkaloids (arecoline, arecaidine, guvacine, and guvacoline) [9]. Previous phytochemical studies have reported that areca nut contains various chemical compounds, especially alkaloids and tannins. Alkaloids have been demonstrated to be the main active constituents responsible for pharmacological action [10].

From the phytochemical screening test, this study showed the flavonoid content in the ethanol extract of Areca seeds. Research on the hydroethanol extract of Areca nut showed the antiinflammatory effects; this mechanism is possible because of the catechin content. The content of catechins, which is a subclass of flavonoids in areca seeds, acts as an anti-inflammatory through COX-2 inhibition mechanism, then inhibits the formation of prostaglandin E2 so that prolonged inflammatory processes can be prevented, and inflammatory responses such as pain and swelling can be stopped [11] [12]. A. catechu, in several reports through in vitro and in vivo trials, has shown effectiveness to combat disorders, such as antimicrobials, antioxidants, or anticancer [13]. The ethanol extract of Areca catechu has also been reported to have the 
anti-inflammatory capacity not only due to the suppression of iNOS and COX-2 but also through the phosphorylation process of NFKB. [14]

\subsection{Isolation of Mononuclear Cells (MNCs) from Bone Marrow of Sprague Dawley Rats}

Femur bones of 10-week old Sprague Dawley mice were collected, and the bone marrow was isolated using centrifugation techniques. Then, the bone marrow obtained was washed using PBS. Centrifugation was performed again to get bone marrow cell deposits containing stromal cells and blood cells (Figure 2).
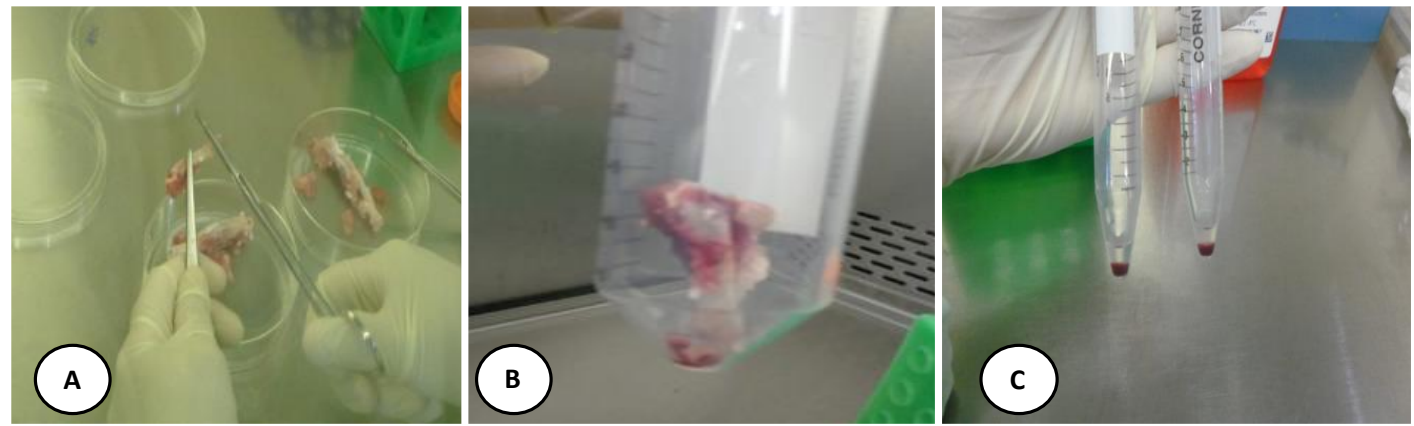

Figure 2. MNC isolation process from rats' bone marrow. A. The collected rats' femur. B. Rats' femur will be centrifuged to obtain bone marrow. C. Bone marrow cell deposits

The cell population from bone marrow was then grown in a mesenchymal stem cell growth medium. This cell population was still heterogeneous, consisting of stromal cells and blood cells (Figure 3).

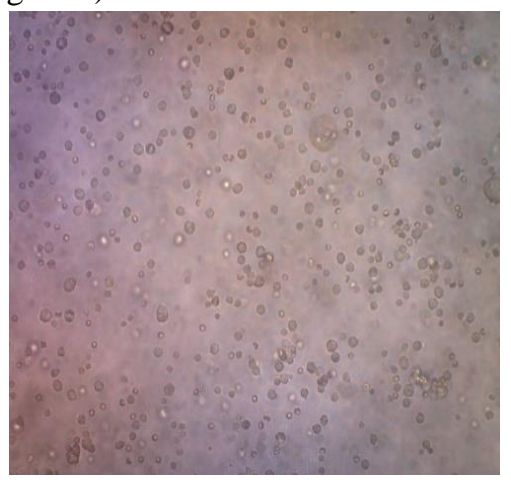

Figure 3. Mononuclear cells from bone marrow on day 0 were cultured in mesenchymal stem cell growth media; the cell population was still heterogeneous.

Cells were grown, and cell colonies were detected on day 3 with spindle-shaped fibroblastlike morphology. This cell population reached $80 \%$ confluence on day 7 (Figure 4). Cells were subcultured to produce a larger number of cells and obtain a homogeneous population.

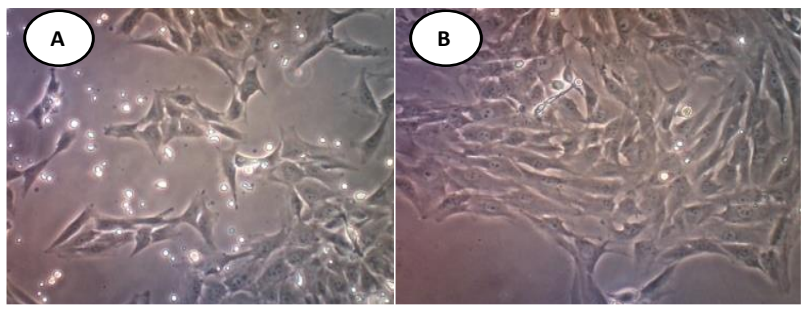

Figure 4. Morphology of bone marrow mesenchymal stem cells day 3 (A) and day 7 (B), with spindle-shaped fibroblast-like morphology, and grew attached to the plastic substrate.

The growth medium in the culture environment contained growth factors that enabled the cells to perform mitosis, thus increasing the cell population. In vitro cell growth is different from in vivo cell growth. Cell growth in an in vitro environment would experience a decrease in cell-tocell interactions, cell-matrix interactions, and require growth factors and nutrients. The culture environment created could help cell growth in vitro, so the cells are able to reproduce themselves, both for cells that do not have a special function and for cells that have been differentiated. 


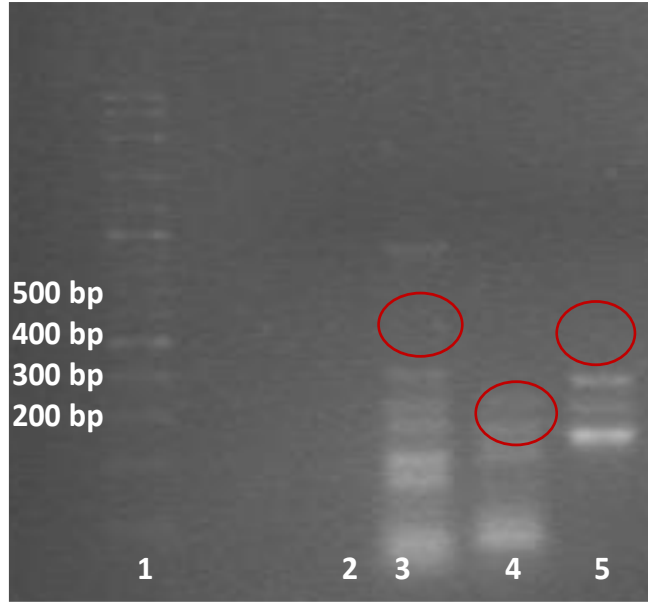

Figure 5. Results of MSCs gene expression in the rats' bone marrow population. This cell population expresses CD73 and CD105 markers, proving that this cell population is MSCs. 1 ladder 100bp, 2. PCR reagent control, 3. CD73 (403bp), 4. CD (225 bp) 5. GAPDH (352 bp).

Mesenchymal stem cells (MSCs) morphology is elongated with fibroblast cell morphology and attaches to the growth site. This cell population also expresses MSCs markers, namely CD73 and CD105, so that it can be used for in vitro test of bioactive compounds and continued for differentiation into chondrocytes. The chondrocytes formed will be used in further research to determine the effect of bioactive compounds as an antiinflammatory.

\subsection{Toxicity Test using the MTT method}

The MSCs population given the addition of Areca nut extract, consisting of ethanol, alkaloid, and flavonoid extracts with concentrations of 500 ppm, 250 ppm, 125 ppm, 62.5 ppm, and 31.75 ppm were incubated for 48 hours, and the inhibition was observed. The results of observations using an inverted microscope showed cell death on the exposure of a 500ppm-concentration of flavonoid extracts (Figure 6).

Observations on the morphology of the dead cells showed abnormal shapes, shrunk, and the cells did not stick to the base where they grew. This may occur because there is damage of adhesion molecules to help adhesion between cells and the cytoskeleton, which functions in cell morphology formation

This population had a limited ability to live due to DNA damage and stress induction. One of the influencing factors can be the formation of Reactive Oxygen Species (ROS) caused by a high oxygen level known to stimulate senescence.

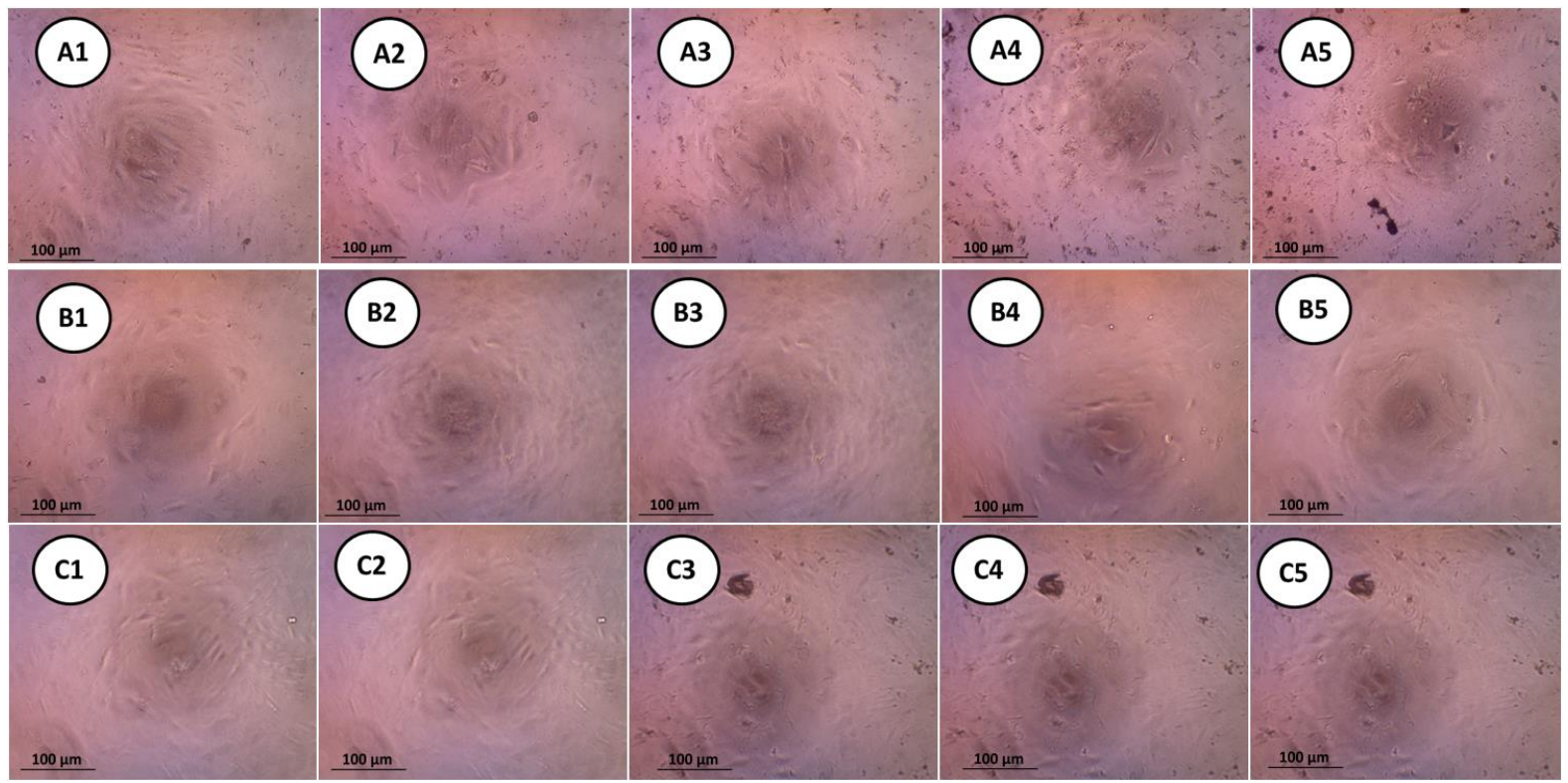

Figure 6. Morphology of MSCs after the administration of Areca nut extract shows that cell viability is above $50 \%$, except for ethanol and flavonoid extracts at a concentration of $500 \mathrm{ppm}$. A. Ethanol Extract, B. Alkaloid Extract, C. Flavonoid Extract.

(1). 31.75 ppm, (2). 62.5 ppm, (3). 125 ppm, (4). 250 ppm, (5). 500 ppm 
Calculation of IC 50 from the MTT test results revealed cell viability percentage above $50 \%$, indicating that the addition of Areca nut extract did not inhibit cell growth (Table 3). The addition of bioactive compounds could affect cell growth through apoptosis and necrosis. Further investigation of the causes of cell death that occurred in this study must be conducted. The concentration of extract that kills normal noncancerous cells in vitro cannot be used for further testing because of the toxic effect on cells.

Table 3. Percentage of cell viability at each extract concentration added to MSCs

\begin{tabular}{|c|c|c|c|}
\hline \multirow{2}{*}{$\begin{array}{c}\text { Concentration } \\
\text { (ppm) }\end{array}$} & \multicolumn{3}{|c|}{ Cell Viability (\%) } \\
\cline { 2 - 4 } & Ethanol Fraction & Alkaloid Fraction & Flavonoid Fraction \\
\hline 500 & 27.84 & 126.42 & 14.69 \\
\hline 250 & 144.46 & 140.91 & 76.24 \\
\hline 125 & 160.22 & 168.04 & 84.56 \\
\hline 62.5 & 149.43 & 182.95 & 78.86 \\
\hline 31.75 & 140.57 & 159.66 & 73.91 \\
\hline
\end{tabular}

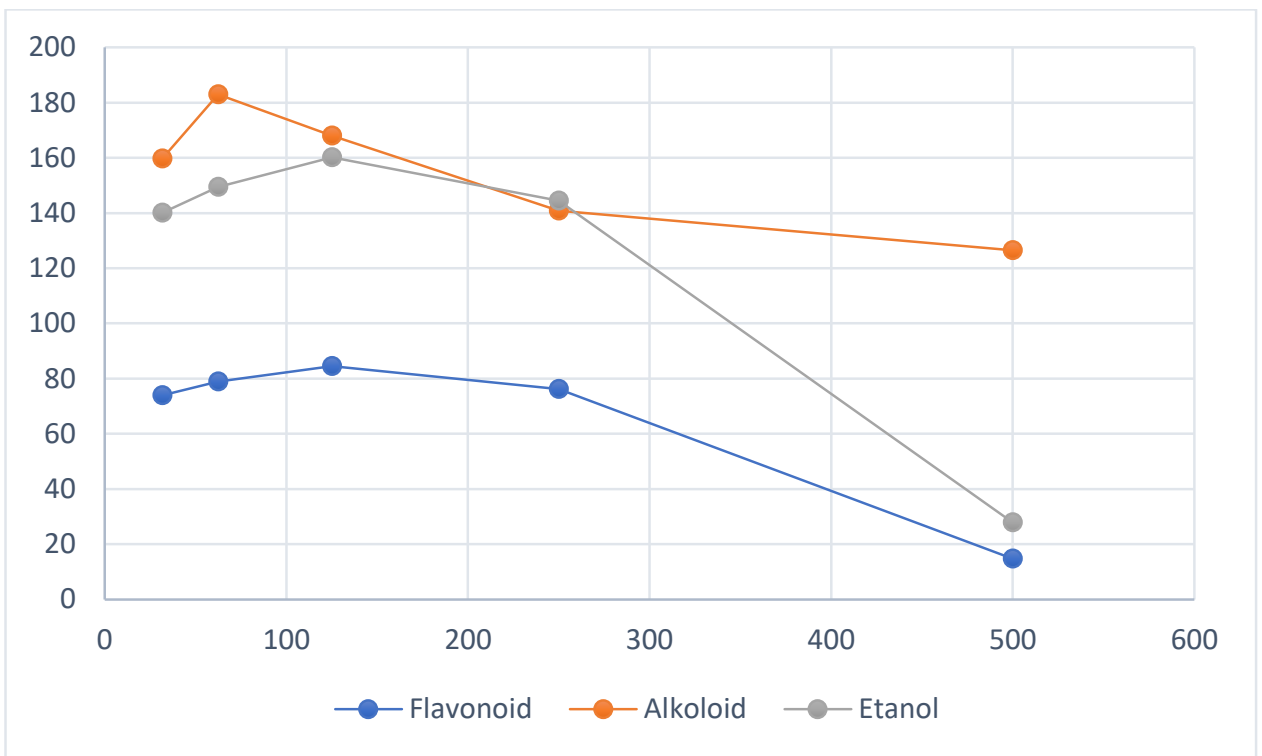

Figure 7. Areca nut extract toxicity to MSCs

\section{CONCLUSION}

In this study, the extraction and fractionation of areca nut (Areca catechu L) were carried out to obtain the active substance in the form of ethanol, alkaloid, and flavonoid compounds. Acute toxicity assessment using the colorimetric Microtetrazolium (MTT) assay method obtained LD50 487.94 ppm. This shows that Areca nut (Areca catechu L.) isolate is non-toxic, so it has the potential to be given to humans as an alternative medicine. Cell isolation has been carried out to obtain mesenchymal stem cells, which will be continued by assessing the effect of treatment by administering alkaloid and flavonoid compounds at doses of 62.5, 125, and 250ppm.

\section{ACKNOWLEDGMENT}

Thank to Faculty of Medicine and Health Sciences, Jambi University for funding this research.

\section{REFERENCES}

[1] E. R. Vina, C. K. Kwoh. 2018. Epidemiology of osteoarthritis: literature update. Curr Opin Rheumatol.;30(2):160-167. doi:10.1097/BOR.0000000000000479

[2] G. Nonaka. 1989. Isolation and structure elucidation of tannins, Pure \& Appl. Chem, 61 (3): 357-360. 
[3] M. S. Amudhan, V. H. Begun, K. B. Hebbar. 2012. A review on phytochemical and pharmacological potential of Areca catehu L seed. IJPSR 3 (11):4151-4157

[4] Humaryanto, A. Olivia, Fairuz. 2019. Exploration of Anti-inflammation Potency of Areca cathecu L. Extract on Rat Model of Osteoarthritis. $4^{\text {th }}$ International Conference on IMERI, Faculty of Medicine, University of Indonesia.

[5] F. Rerung, S. Anam, \& A. Khumaidi. 2017. Isolasi Senyawa Flavonoid Ekstrak Biji Pinang Merah (Areca vestiaria Giseke) Dan Uji Sitotoksiknya Melalui Uji Brine Shirimp Lethality Test (BSLT). GELENIKA Journal of Pharmacy, 3(1): 18-26

[6] M. Angelina, A. Mun'im, \& M. Hanafi. 2011. Ekstraksi Terstandar secara Kimia Daun Brucea javanica Merrill. Indonesian Journal of Applied Chemistry, 13(2): 45-51.

[7] M. Titis, E. Fachriyah, \& D. Kusrini. 2013. Isolasi, Identifikasi dan Uji Aktifitas Senyawa Alkaloid Daun Binahong (Anredera cordifolia (Tenore) Steenis). Chem Info Journal, 1(1): 196-201.

[8] J. B. Harbone. 1987. Metode Fitokimia: Penuntun Cara Modern Menganalisis Tumbuhan. 2 ed. Bandung: ITB Press.

[9] Z. Xing, W. Jiao, H. Zhuang, et al. 2010. Antioxidant and Cytotoxic Phenolic Compounds of Areca Nut (Areca catechu). CHEM. RES. CHINESE UNIVERSITIES. 26(1), 161-164.

[10] W. Peng, Y. Liu, C. Zhao, X. Huang, N. Wu, M. Hu et al. 2015. In silico Assessment of Drug-like Properties of Alkaloids from Areca catechu L Nut. Trop J Pharm Res. 14 (4): 636

[11] A. M. Bhandare, A. D. Kshirsagar, N. S. Vyawahare, A. A. hadambar and V. S. Thorve. 2010, Potential Analgesic, AntiInflammatory And Antioxidant Activities of Hydroalcoholic Extract of Areca Catechu L. Nut, WWW Food Chem Toxicol. 48: 34123417, (serial online) http://www.sciencedirect.com/science/articl e/pii/S0278691510005776 (17 Januari 2013)

[12] P. L. Huang, C. W. Chi and T. Y. Liu. 2010, Effects of Areca catechu L. Containing Procyanidins on Cyclooxygenase-2 Expression in Vitro and in Vivo, WWW Food Chem Toxicol, 48: 306-313 (serial online),

http://www.ncbi.nlm.nih.gov/pubmed/19840 828 (17 Januari 2014)

[13] B. Salehi, D. A. Konovalov, P. Fru, P. Kapewangolo, G. Peron, M. S. Ksenija, et al. 2020. Areca catechu-From farm to food and biomedical applications. Phytother Res. 2020 Sep;34(9):2140-2158. doi: 10.1002/ptr.6665.
[14] K. P. Lee, G. W. Sudjarwo, J. S. Kim, S. Dirgantara, W. J, Maen, H. Hong. 2014. The anti-inflammatory effect of Indonesian Areca catechu leaf extract in vitro and in vivo. Nutr Res Pract. 2014;8(3):267-271. doi:10.4162/nrp.2014.8.3.267 